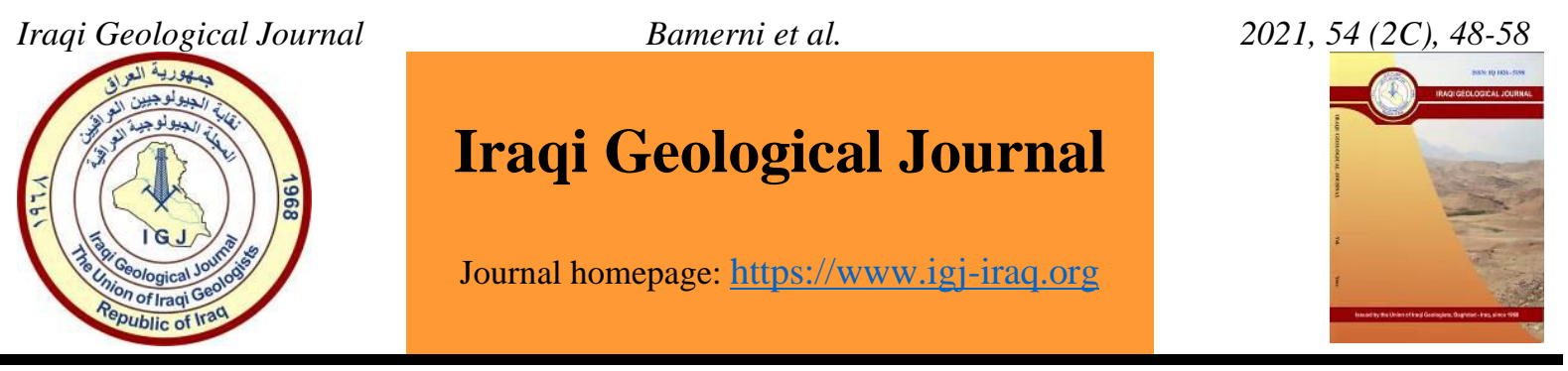

\title{
Foraminiferal Biostratigraphy of the Uppermost Cretaceous Period, Duhok Area, Kurdistan Region, North of Iraq
}

\author{
Abdulrahman Bamerni ${ }^{1}$ * Basim Al-Qayim ${ }^{2}$ and Rund Ali Hammoudi ${ }^{1}$ \\ 1 Department of Geology, College of Science, University of Duhok, Kurdistan Region, Iraq \\ 2 Department of Petroleum Engineering, Komar University of Science and Technology, Sulaimani, Kurdistan Region, Iraq \\ * Correspondence: abdulrahman.qasim@uod.ac
}

Received: 24 April 2021; Accepted: 7 June 2021; Published: 30 September 2021

\begin{abstract}
A relatively complete Late Maastrichtian succession of the upper part of the Shiranish Formation (Upper Cretaceous) in the Duhok area is investigated for the planktic foraminiferal assemblages. This studied interval consists mainly of bluish shale, marl, and thin beds of hard marly limestone all with grey-blue color. The upper contact of the Shiranish Formation is conformable with the overlies Danian Aaliji Formation. Based on the recorded planktic foraminifera and their ranges, the studied succession is subdivided into three main biozones of the latest Maastrichtian age, these zones are Pseudoguembelina hariaensis (CF3) Interval Zone, Pseudoguembelina palpebra (CF2) Interval Zone, and Plummerita hantkeninoides (CF1) Total Range Zone. These zones show continuous and complete Upper Cretaceous sediments, which are preserved in the Bade section of the Duhok area.
\end{abstract}

Keywords: Foraminifera; Biostratigraphy; Maastrichtian; Shiranish; Kurdistan; Iraq

\section{Introduction}

Although the explosion of the calcareous nanoplankton and foraminifera in the warm seas of the Cretaceous is widely reported, for the Tethys realm no precise zonation schemes of the marine fauna are available (Gradstein et al., 2020). According to Renne et al. (2013) in Gradstein et al. (2020) the base of the uppermost Cretaceous (Maastrichtian) started 72.17 Ma ago and the top of the Maastrichtian Stage is anchored to the well calibrated $\mathrm{K} / \mathrm{Pg}$ boundary, placed at $66.04 \mathrm{Ma}$ ago with a duration of 6.13 million years.

The uppermost Cretaceous (Maastrichtian) deposits are represented by the upper part of the Shiranish Formation in the current study. Henson (1940) in Bellen et al. (1959) investigated the uppermost rock unit of the Cretaceous in Duhok and Zakho areas and assigned it as the Shiranish Formation of Maastrichtian age at top, and stated that although the upper part of the Shiranish Formation in the type section is of a continuous sequence of blue marls and without any apparent angular unconformity, but thought that topmost beds of the original Shiranish Formation were removed by erosion and the formation at its top is of Upper Maastrichtian but not uppermost Maastrichtian age. AlOmari $(1966,1970)$ studied the foraminiferal fauna from the upper part of the Shiranish Formation in northwestern Iraq and proved to be of Maastrichtian age. A detailed planktic foraminifera study was

DOI: 10.46717/igj.54.2C.5Ms-2021-09-24 
done by Kassab (1972) for the Shiranish Formation at the type locality, in addition other studies from different localities of Shiranish Formation in North of Iraq (i.e., Kassab, 1974; 1978; 1979) he assigned the lower-middle Maastrichtian age for the upper part of the formation. Al-Qayim and Al-Shaibani (1989) through their study to the Cretaceous-Paleogene contact northwest Iraq, they concluded a relatively long hiatus include the uppermost Maastrichtian of the upper part of the Shiranish Formation. Many studies of the uppermost Cretaceous deposits in Iraq and Kurdistan Region suggested that the Cretaceous ends with probably abrupt, erosional, paraunconformity or hiatus among them (Al-Safawee, 1982; Al-Mutwali, 1983; Al-Shaibani and Al-Qayim, 1986; Kassab, 1986; Ghafor, 1988; Al-Qayim and Al-Shaibani, 1995; Al-Omari et al., 1994; Awadh et al., 2008; Al-Hadiedi, 2010; Hammoudi, 2011; AlMutwali and Al-Doori, 2012; Al-Wazan, 2013; Al-Mutwali and Ibrahim, 2019; Al-Dulaimi and Abdallah, 2019). In contrast, other foraminiferal biostratigraphic studies have supported the occurrence of complete uppermost Maastrichtian deposits (Sharbazheri et al., 2009 and 2011; Salih et al., 2013; Mousa et al., 2020; Al Nuaimy et al., 2020). The current high resolution biostratigraphic study aims to prove the occurrence of complete uppermost Maastrichtian deposits throughout the planktic foraminiferal assemblages and its biozonations for the upper part of the Shiranish Formation, Duhok area, Kurdistan Region, North of Iraq.

\section{Geological Setting}

The current study is based on a high-resolution investigation of the planktic foraminifera of a stratigraphic outcrop in the Duhok area, namely Bade section that is located about $15.6 \mathrm{~km}$ NE Duhok city and exposed on the northern limb of the Bekhair anticline at exact coordination of latitude $36^{\circ} 53^{\prime} 52.98^{\prime \prime} \mathrm{N}$ and longitude $43^{\circ} 5^{\prime} 5.50 " \mathrm{E}$. The studied area is located within the High Folded Zone of the Outer Platform of Western Zagros Fold Thrust Belt (WZFTB) according to the tectonic divisions of Iraq by Fouad (2015) (Fig. 1).

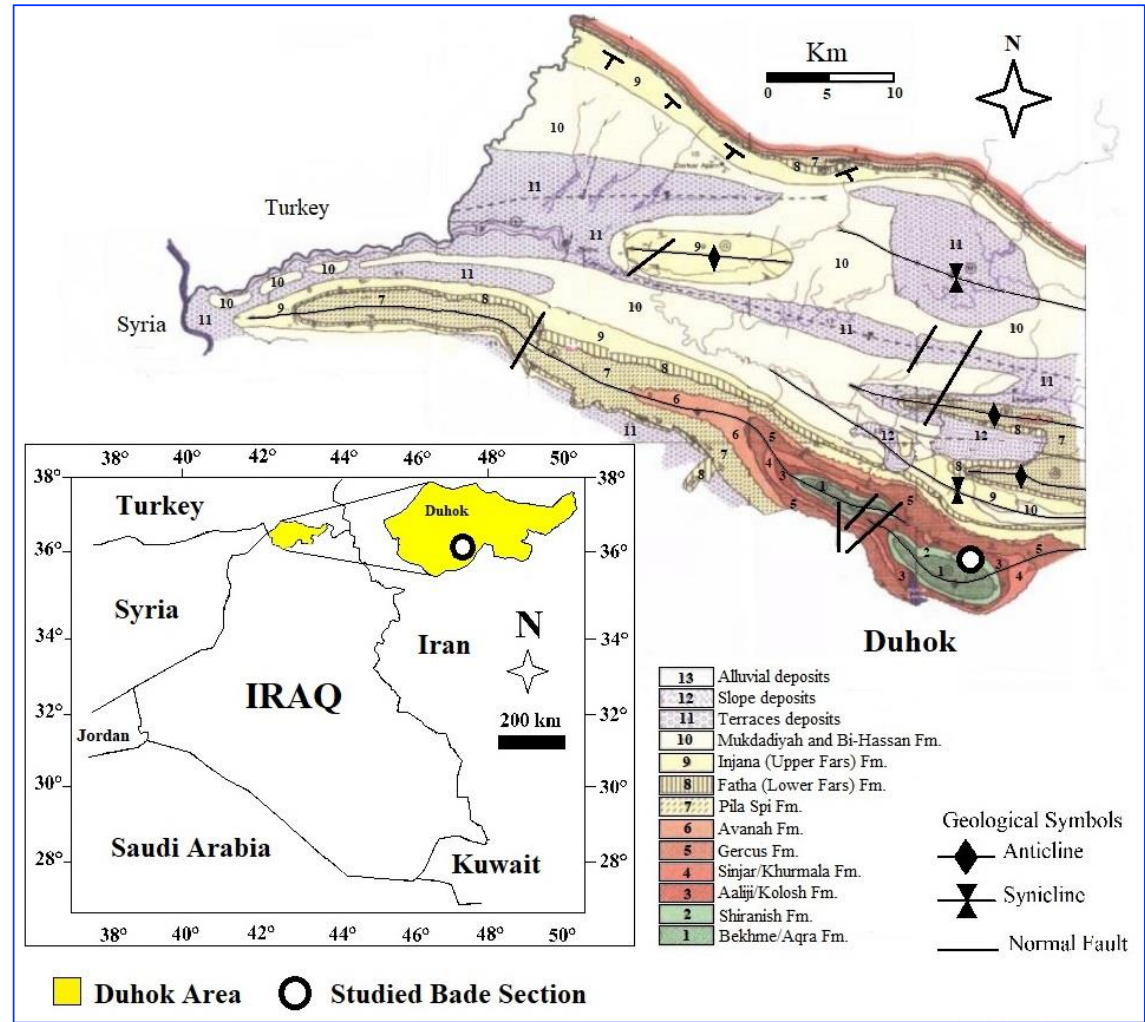

Fig. 1. Location map of the studied section, with general geology of the Bekhair anticline (Abdulla, 2013) 
The studied uppermost Maastrichtian deposits belong to the Ninth Arabian Plate Megasequence (AP9) that extends in age from Middle Turonian to Middle Eocene (Al-Qayim, 2019). The Shiranish Formation is well exposed within the Bekhair anticline, which consists of double plunging fold, with two main directions of trends. The first trend is parallel to the direction of the Zagros Range (NW-SE), whereas the other coincides with the direction of the Taurus Range (E-W) occupying a large area extending from Geli Zawita (eastern plunge) at Duhok to Deraboone village (western plunge) on the Iraqi-Syrian-Turkish borders (Al-Azzawi and Al-Hubiti, 2009). Stratigraphically, Bekhair anticline represents one of the main anticlines within the High Folded Zone of the WZFTB in Duhok area (Fouad, 2015). It comprehends outcrops from Late Cretaceous to Pliocene in age and including AP9, AP10 and AP11 Late Turonian - Danian; Middle Paleocene - Eocene and Latest Eocene - Recent Arabian Plate Tectonic Megasequences (Jassim and Goff, 2006).

The Shiranish Formation of the current study named after Shiranish Islam village, which lies on the southern limb of Khamteer anticline, to the northeast of Zakho city. The type section of the Formation firstly described by Henson (1940) In Bellen et al. (1959) below and above the village at Long. 37 $11^{\prime} 32^{\prime \prime} \mathrm{N}$; Lat. $42^{\circ} 50^{\prime} 30^{\prime \prime}$ E. Shiranish Formation in its type section is of $227.8 \mathrm{~m}$ Globigerinal sediments, consisting of upper division of $99 \mathrm{~m}$ of blue marls, overlying lower division of $128.8 \mathrm{~m}$ of thin bedded marly limestone. All having a typical pale blue color that increase in darkness with increasing of bituminous. Conformably overlies the limestone of Bekhme Formation, while its upper contact seemingly conformable, but it marks a faunal break, corresponding to the Cretaceous-Paleogene contact, with the Lower Paleocene marl of the Aaliji Formation (Bellen et al., 1959).

\section{Materials and Methods}

Two sets of sampling were collected in the current study: a) preliminary sampling for constraining the end of the uppermost Maastrichtian deposits of the Shiranish Formation and b) high-resolution sampling for detailed biostratigraphical investigations. On overall, (39) fresh rock samples were collected from the upper part of the Shiranish Formation in the studied Bade section. Later in the laboratory, the retrieving of the calcareous foraminifera from the lithified lime deposits depends mainly on the "Cold Acetolyses" techniques called as Lirer (2000) method. Fresh extracted samples were dried at room temperature, softly crushed into small sized fragments (not less than $3 \mathrm{~mm}$ ), put in coveredbeaker and digested in cold, highly concentrate Acetic Acid with $2 \mathrm{~cm}$ level higher than the residue, continuously checking for the treated samples to note the deposition of fine residue on the bottom of the beaker. The time of disaggregation varied according to the hardness and lithology. 3, 5 and 7 hours were recorded due to different lithology as shale, marl and limestone respectively. As soon as the reaction ends with turning the liquid acid into dense substance. Samples washed under strong water current, sieved through the standard ASTM sieves $(250,177,149,125$ and, $63 \mu \mathrm{m})$ and dried at room temperature. After this procedure, the residue should be free of inorganic matter and the foraminifera tests supposed to be clean and ready to be examined under stereomicroscope. Otherwise, the residue dipped again in beaker containing water diluted Desogen and gone under Ultrasonic cleaner till getting the satisfying results. All materials are stored at Department of Geology, University of Dohuk (Kurdistan Region of Iraq). In this study, authors followed the biozonal schemes of Li and Keller (1998 a, b); Coccioni and Premoli Silva (2015) for the Late Maastrichtian.

\section{Results and Discussion}

\subsection{Lithostratigraphy}

The studied section named after the nearby Bade village, it is about $15.6 \mathrm{~km}$ to the northeast of Duhok. The investigated uppermost Maastrichtian sediments of Bade section is $23.30 \mathrm{~m}$ in thickness, 
belong to the upper part of the Shiranish Formation (Henson, 1940 in Bellen et al., 1959). The described interval of the Shiranish Formation in the current study consists of marl and marly limestone interbedded with soft shale intervals, all with bluish grey color. The lower part of the this studied interval shows a soft grey-blue shale of about $(8.5 \mathrm{~m})$ thickness, overlies by $(6.2 \mathrm{~m})$ of soft marl interbedded with hard marly limestone $(20-30 \mathrm{~cm})$ beds. All dark grey - blue in color, following by (5.6) $\mathrm{m}$ of soft bluish marl. The uppermost part of Shiranish Formation in this section is around $(3 \mathrm{~m}$ ) of hard bluish marl (Fig. 2).

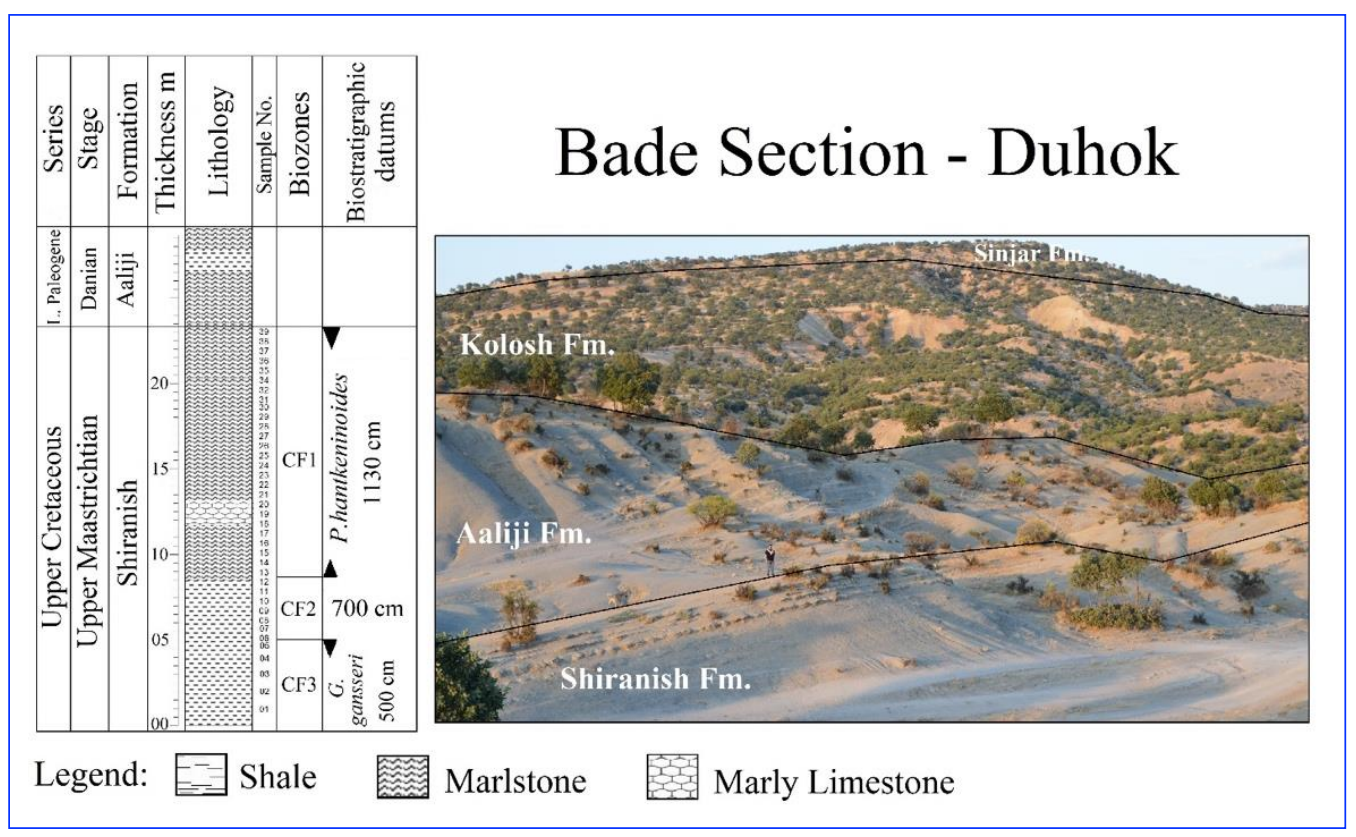

Fig. 2. The lithologic column of the studied succession and a field photo of the stratigraphic succession of the studied Bade section, Duhok

On the other hand, the light brown and soft marl of the Danian Aaliji Formation (Bellen, 1950 In Bellen et al., 1959) starts directly above the pelagic blue marl of the Shiranish Formation in Duhok area in general and in the studied Bade section as well, representing the continuous transition of the Cretaceous and Paleogene sediments in the area (Bamerni et al., 2020) (Figs. 3 A, B, C).

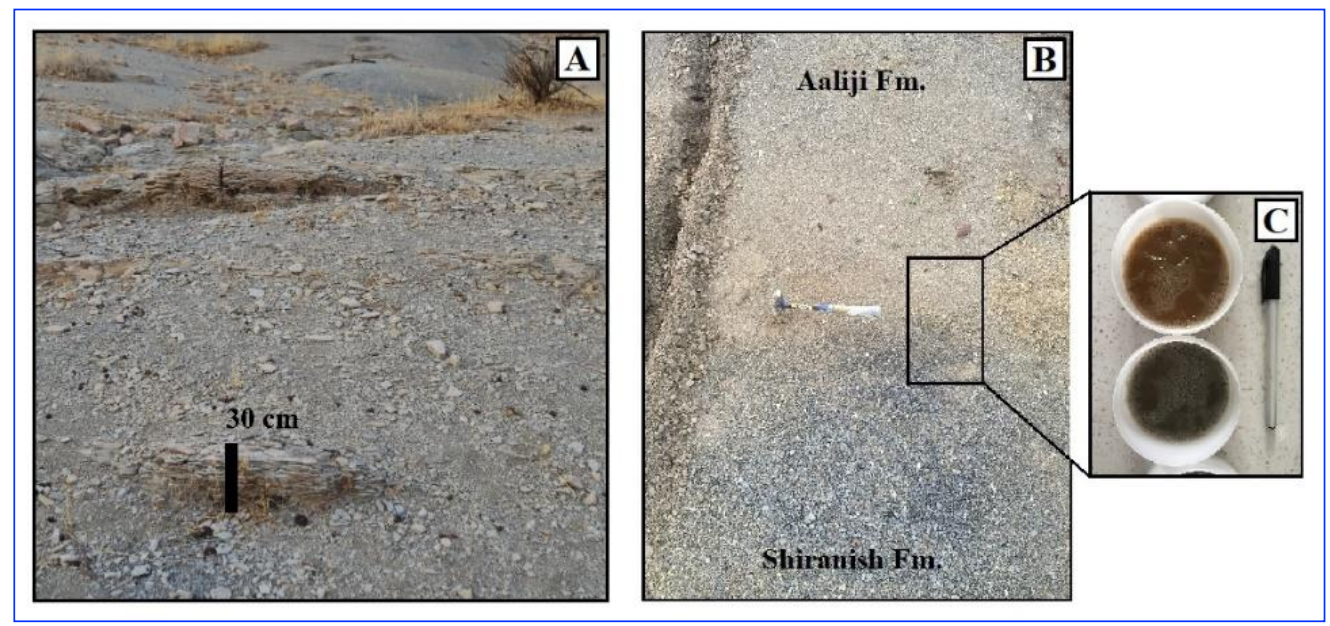

Fig. 3. A. Hard marly limestone beds; B. Field photo of the upper contact of the Shiranish Formation with the overlies Aaliji Formation in Bade section; C. Color variation of laboratory treated sediments between Cretaceous and Paleogene marls 


\subsection{Biostratigraphy}

Thirty-nine planktic foraminiferal species belong to fifteen genera were recorded through the highresolution investigation of the uppermost Maastrichtian deposits of the studied interval of the Shiranish Formation in the Bade section. Genera showed good diversity with abundance of species mainly for Heterohelix, Pseudoguembelina, Globotruncana, Globotruncanita, Plummerita, Planoglobulina, Rugoglobigerina, Pseudotextularia, Globotruncanella and Racemiguembelina respectively. Also, rare occurrence of species belong to typical late Maastrichtian genera were identified, among them: Trinitella, Gansserina, Guembeliteria and Abathomphalus.

The following is an alphabetical order of the generic abbreviations discussed in this study: Abathomphalus = Ab., Archaeoglobigerina = Ar., Gansserina = Ga., Globotruncana = Gana., Globotruncanella = Glla., Globotruncanita $=$ Gita., Gublerina $=$ Gu., Guembelitria $=$ G., Hedbergella $=$ Hed., Heterohelix = Hx., Planoglobulina = Plg., Plummerita = Pl., Praemurica $=$ Pr., Pseudoguembelina $=$ Psg., Pseudotextularia $=$ Pst., Racemiguembelina $=$ Rac., Rugoglobigerina $=$ Rug., Trinitella $=\mathrm{T}$. The most important bioevents recorded in the current biostratigraphical investigations are: the highest occurrence (HO) of Ga. gansseri (Bolli) (Pl.1, Fig. 3), Abundance of Hx. navarroensis Loeblich (Pl.1, Fig.5) in the top part of the Maastrichtian deposits, Rare occurrence and disappearance of Ab. mayaroensis (Bolli) (Pl.1, Figs. 1,2) few meters above the $\mathrm{HO}$ of Ga. gansseri (Bolli). The lowest occurrence (LO) of the Pl. hantkeninoides (Brönnimann) (Pl.1, Fig. 15), Pl. cf. hantkeninoides (Brönnimann) (Pl.1, Fig. 14) and G. cretacea Cushman (Pl.1, Fig. 14) were synchronous.

According to Coccioni and Premoli Silva (2015) the HO of Ga. gansseri (Bolli) is dated (66.53 Ma), and defined the base of the planktic foraminiferal Pseudotextularia elegans Zone of their study, that is equivalent to the base of CF2 of Li and Keller (1998 a, b). On the other hand, they concluded that the LO of Pl. hantkeninoides (Brönnimann) dated as (66.15 Ma) and pointed the base of the nominated zone. Based on the ranges of the planktic foraminiferal fauna recorded in the current study, three main Late Maastrichtian zones were identified throughout the upper part of Shiranish Formation in the studied Bade section, Duhok area (Fig. 4).

\subsubsection{Planktic foraminiferal biozones}

- Pseudoguembelina hariaensis (CF3) interval zone part (Late Maastrichtian)

The CF3 Zone is defined as interval span from the LO of the nominated zonal marker Psg. hariaensis Nederbragt to the $\mathrm{HO}$ of Ga. gansseri (Bolli). In the investigated Bade section of Duhok area, only the upper part of this zone was recognized in the current high-resolution study. The studied part of this zone is represented by interval of $5 \mathrm{~m}$ thickness.

The planktic foraminiferal assemblages recorded in this zone showed a good level of preservation. It showed main abundance of Pst. elegans (Rzehak) (Pl.1, Fig. 6), Gita. stuarti (de Lapparent), Hx. globulosa (Ehrenberg), Gana. aegyptiaca Nakkady, Gita. stuartiformis (Dalbiez), T. scotti (Brönnimann) (Pl.1, Fig. 12), Rug. rugosa (Plummer) (Pl.1, Fig. 11) with common occurrences of Plg. carseyae (Plummer), Hx. labellosa (Nederbraget), Hx. reussi (Cushman), Psg. costulata (Cushman), Psg. hariaensis Nederbraget (Pl.1, Fig. 7), Gana. arca (Cushman), Hx. striata (Ehrenberg), Rug. hexacamerata Brönnimann, Pst. intermedia Rzehak, Plg. brazoensis Martin. Associated with rare occurrences of Ga. gansseri (Bolli), Rac. powelli Smith and Pessagno, Rug. macrocephala Brönnimann, Pl. reicheli (Brönnimann) (Pl.1, Fig. 13), Hed. monmouthensis (Olsson) and Ar. blowi Pessagno (Fig. 4). 


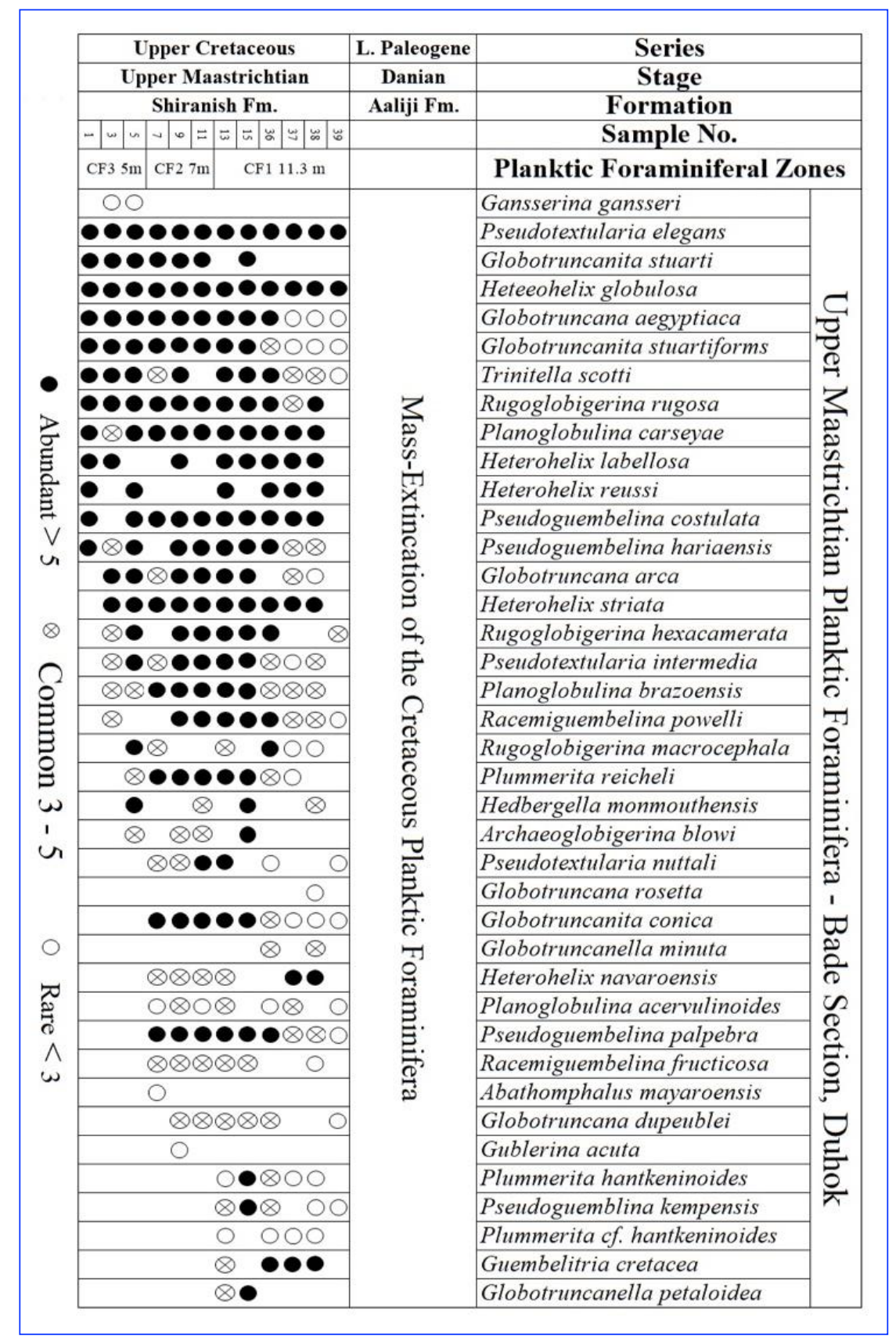

Fig. 4. Planktic foraminiferal species and their ranges of the Bade section, datum plains of the zones follow Li and Keller (1998 a, b) and Coccioni and Premoli Silva (2015)

The zonal marker is easily to recognize and commonly abundant in this zone. This zone is equivalent to the middle part of Abathomphalus mayaroensis Zone, recorded by Abawi et al. (1982), Al-Qayim and Al-Shaibani (1989), Al-Mutwali (1992), northern of Iraq. Hammoudi (2011) considered the CF3 Zone as subzone within the Abathomphalus mayaroensis Zone. The current Pseudoguembelina hariaensis (CF3) Zone is equivalent to the same CF3 Zone recorded by many authors as: Sharbazheri (2008), Sharbazheri et al. (2011), Al-Mutwali and Al-Doori (2012), Salih et al. (2013), Al-Mutwali and Ibrahim (2019), Al Nuaimy et al. (2020) from different localities north of Iraq. Also, the CF3 Zone is correlated to the same zone of Mousa et al. (2020) from the Western Desert of Iraq. (Fig. 5). 


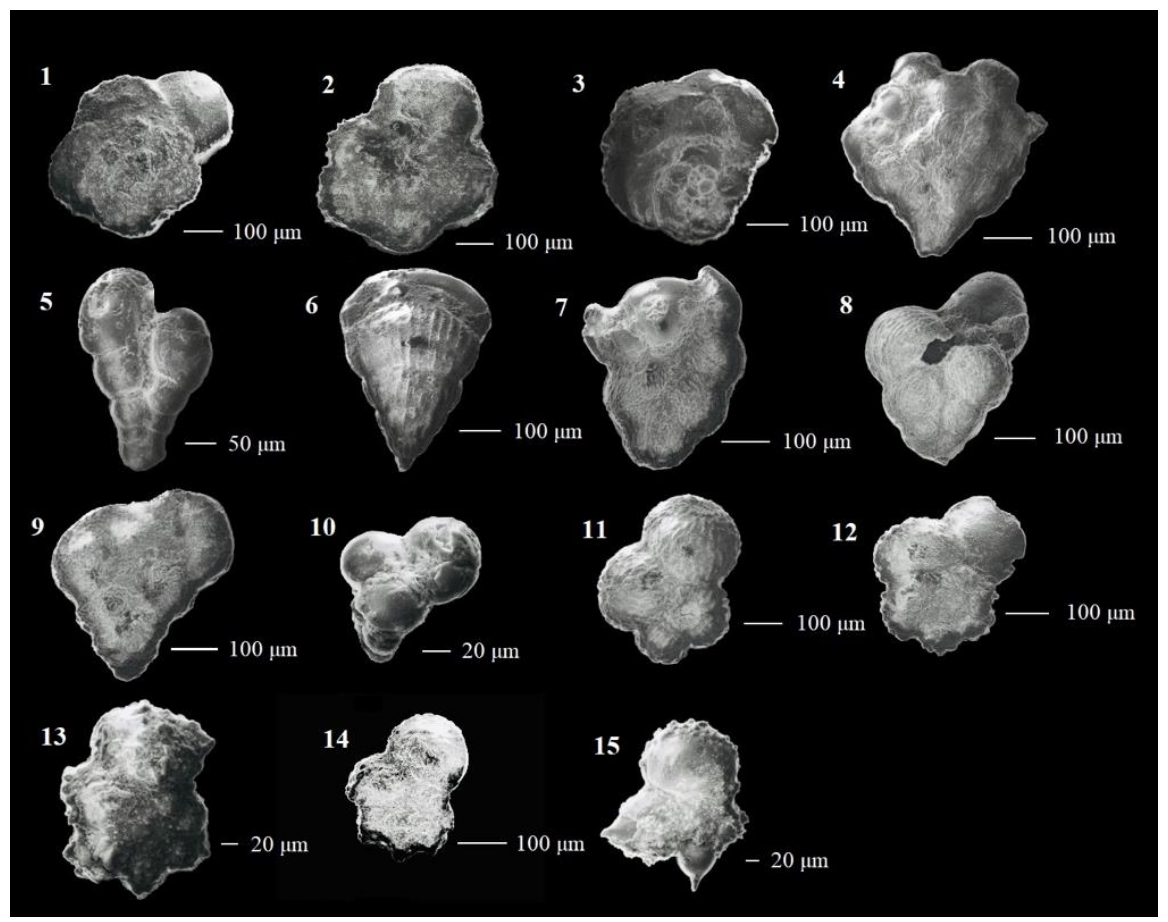

Plate 1. Some index planktic foraminifera from the Upper Maastrichtian Shiranish Formation of Bade section, Duhok. 1-2: Abathomphalus mayaroensis (Bolli, 1951) (sample 7); 3: Gansserina gansseri (Bolli, 1951) (sample 5); 4: Planoglobulina acervulinoides (Egger, 1900) (sample 37); 5: Heterohelix navarroensis Loeblich 1951 (sample 38); 6: Pseudotextularia elegans (Rzehak, 1891) (sample 1); 7: Pseudoguembelina hariaensis Nederbragt 1991 (sample 11); 8: Pseudoguembelina palpebra Brönnimann and Brown 1953 (sample 7); 9: Gublerina acuta De Klasz 1953 (sample 9); 10: Guembelitria cretacea Cushman 1933 (sample 36); 11: Rugoglobigerina rugosa (Plummer, 1927) (sample 15); 12: Trinitella scotti Brönnimann 1952 (sample 5); 13: Plummerita reicheli (Brönnimann, 1952) (sample 7); 14: Plummerita cf. hantkeninoides (Brönnimann, 1952) (sample 38); 15: Plummerita hantkeninoides (Brönnimann, 1952) (sample 15).

\section{- Pseudoguembelina palpebra (CF2) interval zone (late Late Maastrichtian)}

The CF2 Zone is defined as the interval from the HO of Ga. gansseri (Bolli) and the LO of Pl. hantkeninoides (Brönnimann). The Pseudoguembelina palpebra Interval Zone is identified in the studied Bade section with a thickness of $(7 \mathrm{~m})$. This Zone showed continuity of the abundant planktic foraminifera recognized in the previous CF3 Zone. In addition to the abundance of the zonal marker Psg. palpebra Brönnimann and Brow, and Gita. conica (White). As well as rare occurrences of $H x$. navarroensis Loeblich, Plg. acervulinoides (Egger) and Rac. fructicosa (Egger). The Pseudoguembelina palpebra Zone of this study is recognized with the disappearance of Ab. mayaroensis (Bolli) at the base of this zone. The Pseudoguembelina palpebra Zone can be correlate with the upper part of the Abathomphalus mayaroensis Zone, which is recorded by different authors in Kurdistan and Northern Iraq (e.g., Abawi et al., 1982; Al-Qayim and Al-Shaibani, 1989; Al-Mutwali, 1992). This zone is also comparable to the Pseudoguembelina palpebra CF2 Zone of Hammoudi (2011) from Shaqlawa area, Al-Mutwali and Al-Doori (2012), Salih et al. (2013), Al-Mutwali and Ibrahim (2019) from north of Iraq. The CF2 Zone of the current study is match to the same zone recorded by Mousa et al. (2020) from the Western Desert of Iraq and Al Nuaimy et al. (2020) from Sulaimani area NE Iraq (Fig. 5). 


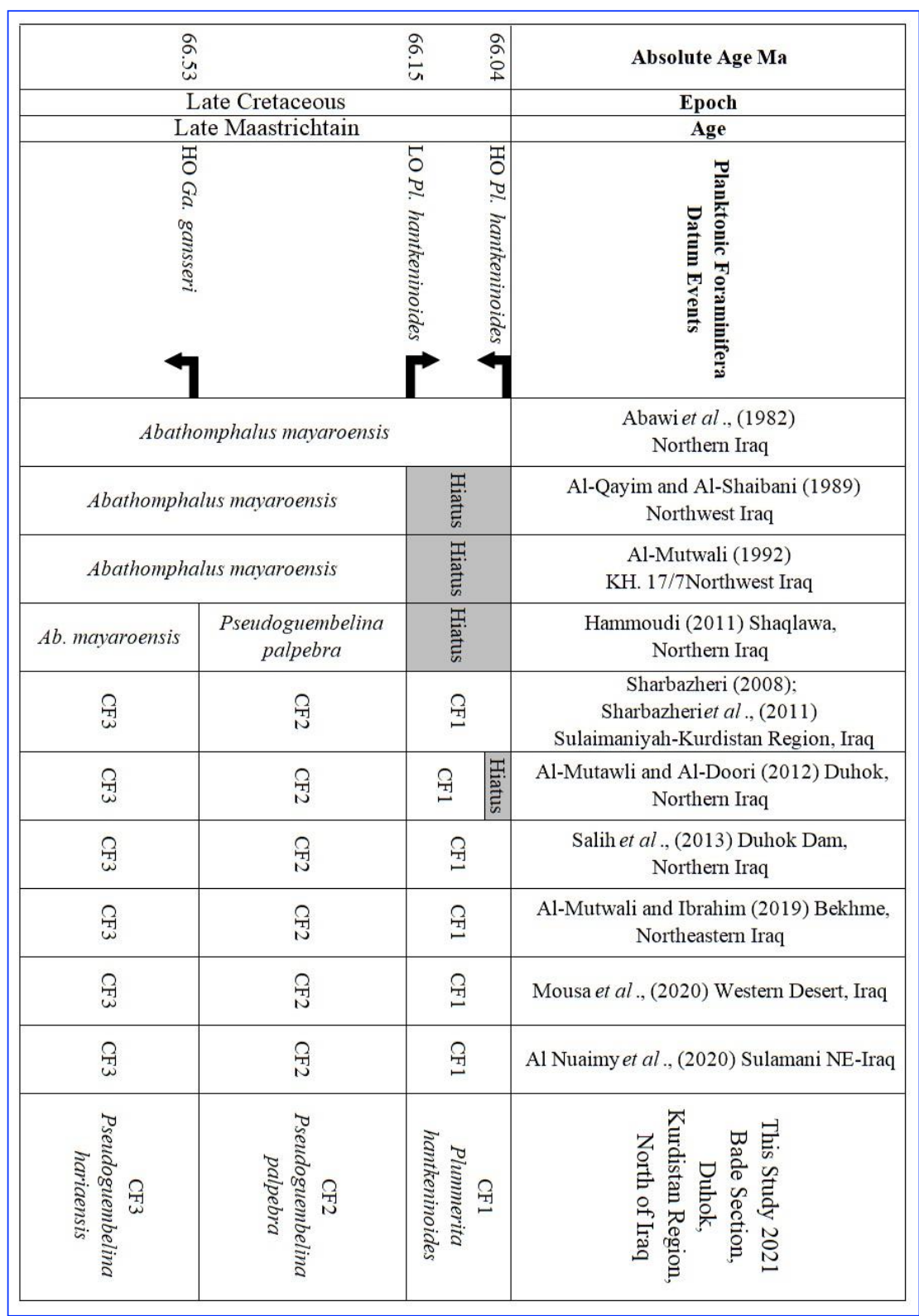

Fig. 5. Regional correlation of the planktic foraminiferal zones of this study with other studies across Kurdistan region and Iraq. Late Maastrichtian ages are after Coccioni and Premoli Silva (2015)

\section{- Plummerita hantkeninoides (CF1) total range zone (Latest Maastrichtian)}

The Plummerita hantkeninoides Zone is defined as the interval from the LO of the zonal marker to the extinction of most of the Cretaceous planktic foraminifera including $\mathrm{Pl}$. hantkeninoides (Brönnimann). The CF1 Zone in the current study is span an interval of $11.30 \mathrm{~m}$ in thickness. The Plummerita hantkeninoides Total Range Zone in the current high-resolution biostratigraphic analysis of the Bade section in the Dohuk area shows a great diversity of the planktic foraminiferal assemblages comparing to the CF2 and CF3 zones. It yields abundant, diverse and good to moderately preserved specimens of Pst. elegans (Rzehak), Gita. stuarti (De Lapparent), Hx. globulosa (Ehrenberg), Rug. rugosa (Plummer), Plg. carseyae (Plummer), Hx. labelosa Nederbragt, Hx. reussi (Cushman), Psg. costulata (Cushman), Hx. striata (Ehrenberg), Hx. navaroensis Loeblich and G. cretacea Cushman. In addition, common occurrence of: Pl. reicheli (Brönnimann), Psg. hariaensis Nederbragt, Psg. palpebra Brönnimann and Brown (Pl.1, Fig. 8), Psg. kempensis Esker, Gana. arca (Cushman), Gana. 
rosetta (Carsey), Plg. brazoensis Martin, Plg. acervulinoides (Egger), and rare occurrence of $\mathrm{Pl}$. hantkeninoides (Brönnimann).

The Plummerita hantkeninoides Zone represents the latest Maastrichtian foraminiferal biozone and has been introduced by Masters (1984) through his comparison of the planktic foraminifera at the K/Pg boundary in Tunisia and Egypt. Coccioni and Premoli Silva (2015) stated that the zonal marker is very rare and, sporadically, presented through their revision and identification of the CF1 Zone at the classical Tethyan Gubbio section (Italy). Sharbazheri (2008) and Sharbazheri et al. (2011) recorded the CF1 Zone in their study of the Cretaceous/Paleogene boundary in Sulaimani area of Kurdistan Region. Salih et al. (2013) and Al-Mutwali and Ibrahim (2019) recorded the same zone from Northern and Northeastern Iraq. The Plummerita hantkeninoides Zone is correlated to the same zones of Mousa et al. (2020) from the Western Desert of Iraq and Al Nuaimy et al. (2020) from Sulaimani North East of Iraq (Fig. 5).

\section{Conclusions}

The high resolution planktic foraminiferal biostratigraphy in the Bade section of the Duhok area, shows that the upper part of the pelagic bluish deposits of the Shiranish Formation are of uppermost Cretaceous (Latest Maastrichtian) age. The recorded ranges of the identified planktic foraminifera reveal a continuous and complete sedimentation throughout the upper Cretaceous sediments in the studied section. Depending on the recognized planktic foraminiferal species, the studied interval is subdivided into three main zones of the Upper Cretaceous. These zones are Pseudoguembelina hariaensis p.p. (CF3) Interval Zone, Pseudoguembelina palpebra (CF2) Interval Zone and Plummerita hantkeninoides (CF1) Total Range Zone. Based on these zones, this study concluded the latest Maastrichtian age for the studied sequence.

\section{Acknowledgements}

The authors acknowledge the supporting of the Departments of Geology in Sulaimani and Duhok universities. For the SEM microphotographs, authors thank Kurdistan Institution for Strategic Studies and Scientific Research (KISSR). We thank the peer-reviewers for their valuable comments. The authors are very grateful to the Editor in Chief Prof. Dr. Salih M. Awadh, the Secretary of the Journal Mr. Samir R. Hijab and the Technical Editors for their great efforts and valuable comments.

\section{References}

Abawi, T. S., Abdel-Kireem, M. R. and Yousef, G. M., 1982. Planktonic foraminiferal stratigraphy of the Shiranish Formation, Sulaimaniah-Dokan region Northeastern Iraq. Revista Espanola de Micro aleontologia, 14 (1): $153-164$

Abdulla, H. H., 2013. Rock slope analysis in Duhok Governorate, Bekhair Anticline by using GIS Technique. Journal of Al-Nahrain University. 16 (4), 46-54.

Al Nuaimy, Q. A. M., Sharbazheri, K. M. I., Karim, K. H. and Ghafor, I. M., 2020. Cretaceous-Paleogene Boundary Analysis by Planktic Foraminiferal Biozonation in the Western Zagros Fold-Thrust Belt (Smaquli valley), Sulaimani Governorate, NE-Iraq. Kirkuk University Journal, Scientific studies (KUJSS), $15(3), 45-81$

AL-Azzawi, N. K. and AL-Hubiti, S. T., 2009. The fold style variations of Baikher Anticline, Northern Iraq. Iraqi Journal of Earth Sciences, 9 (1), 1- 20.

Al-Dulaimi, S. I. and Abdalla, F. T., 2019. Facies analysis of the Upper Cretaceous - Tertiary Succession in selected sections from Northern Iraq. Iraqi Bulletin of Geology and Mining, 15 (2), 17- 34

Al-Hadiedi, A. S., 2010. Planktonic foraminiferal biostratigraphy of Shiranish Formation in Makhmur Well No. (1), Makhmur Area, Northern Iraq. Iraqi National Journal of Earth Sciences, 10 (2), 19-28.

AL-Mutwali, M. M. and AL-Doori, M. A., 2012. Planktonic foraminiferal biostratigraphy of Shiranish Formation in Dohuk Area, Northern Iraq. Iraqi National Journal of Earth Sciences, 12 (3), 17-40. 
AL-Mutwali, M. M. and Ibrahim, M. K., 2019. Planktonic foraminiferal biostratigraphy of Tanjero Formation (Late Maastrichtian) in Bekhme Area, Northeastern Iraq. Iraqi National Journal of Earth Sciences, 19 (1), 1-21.

Al-Mutwali, M. M., 1983. Biostratigraphy of Kolosh Formation and the Nature of its Contact with Upper Cretaceous Rocks in Shaqlawa Area, NE Iraq. Unpublished M.Sc. thesis. University of Mosul, 154 pp.

AL-Mutwali, M. M., 1992. Foraminifera, Stratigraphy and Sedimentology of the Upper Cretaceous and Lower Tertiary in Selected Boreholes around Khleisia-Anah-Ramadi Area.Unpublished Ph.D. thesis, University of Mosul, 268 pp.

AL-Omari, F. S., 1966. Upper Cretaceous-lower Cenozoic Foraminifera from an Oil Well in northwestern Iraq. Unpublished M.Sc. thesis. University of Missouri-Rolla, 107 pp.

AL-Omari, F. S., 1970. Upper Cretaceous and Lower Cenozoic Foraminifera of Three wells in Northwestern Iraq. Unpublished Ph.D. thesis, University of Missouri-Rolla, 208 pp.

Al-Omari, F. S., Kassab, I., and Dawood, S., 1994. Planktonic foraminifera and biostratigraphy of Shiranish and Aaliji Formation in well Mushorah No. 1, Northwestern Iraq. Iraqi Geological Journal, 27 (1), 60-74.

Al-Qayim, B. and Al-Shaibani, S., 1989. Stratigraphic analysis of Cretaceous-Tertiary contact, Northwest Iraq. Journal of Geological Society, Iraq. 22 (1), 41-52.

Al-Qayim, B. and Al-Shaibani, S., 1995. Lithostratigraphy of the Cretaceous - Tertiary Transect, Bekhme Gorge, Northeast Iraq. Iraqi Geological Journal, 28 (2): 127 - 136.

AL-Qayim, B., 2019. Stratigraphic Differentiation of the Zagros Foreland Basin Sequence, Kurdistan Region, (Northern Iraq): Impacts on Oil Accumulations. In: Boughdiri, M., Bádenas, B., Selden, P., Jaillard, E., Bengtson, P., Granier, B. R. C., Eds., Paleobiodiversity and Tectono-Sedimentary Records in the Mediterranean Tethys and Related Eastern Areas, 267 - 269.

Al-Safawee, A. M., 1982. Foraminiferal Study of the Mesozoic-Cenozoic transition of Sasan well (No.1), Northwestern Iraq. Unpublished M.Sc. thesis. University of Mosul, 146 p.

Al-Shaibani, S.K., Al-Qayim, B. A. and Salman, L., 1986. Stratigraphic analysis of Tertiary-Cretaceous contact, Dokan, North Iraq. Journal of the Geological Society of Iraq, 19 (2), 1-26.

Al-Wazan, A. M., 2013. Biostratigraphy of Shiranish Formation in K-306 Well, Kirkuk Area, Northern Iraq. Iraqi National Journal of Earth Sciences, 13 (1), 15-28.

Awadh, S.M., Habib, H.R. and Al-Bassam, K.S., 2008. Upper Cretaceous carbonate hosted zinc-lead-barite deposits in Northern Thrust Zone, northern Iraq: petrography and geochemistry. Arabian Journal of Geosciences, 1(1), 75-85.

Bamerni, A., Al-Qayim, B., and Hammoudi, R. A., 2020. High resolution biostratigraphic analysis of the Danian Stage, Per Fat Section, Duhok Area, Kurdistan Region, North of Iraq. Iraqi Geological Journal, 53 (2B): $113-126$.

Bellen, R. C. van, Dunnington, H. V., Wetzel. R., and Morton, D., 1959. Lexique Stratigraphique, International. Asie, Iraq, 3c (10a): 333.

Coccioni, R. and Premoli Silva, I., 2015. Revised Upper Albian-Maastrichtian planktonic foraminiferal biostratigraphy and magnetostratigraphy of the classical Tethyan Gubbio section (Italy). Newsletters on Stratigraphy, 48 (1), 47-90.

Fouad, S. F. A., 2015. Tectonic Map of Iraq, Scale 1: 1000 000, 3rd edition, 2012. Iraqi Bulletin of Geology and Mining, 11 (1), 1-7. Papers of the Scientific Geological Conference. Part 2.

Ghafor, I. M., 1988. Planktonic Foraminifera and Biostratigraphy of Aaliji Formation and its nature of contact with Shiranish Formation in Tel Hajar well no. 1, Sinjar area, North West Iraq. Unpublished M.Sc. thesis, University of Salah Al-Deen, Iraq, 178 pp.

Gradstein, F. M., Ogg, J. G., Schmitz, M. D. and Ogg, G. M., 2020. Geologic Time Scale $1^{\text {st }}$ Edition. Elsevier, $1390 \mathrm{pp}$.

Hammoudi, R. A., 2011. High resolution biostratigraphy of the K/T boundary in the Higran Section, Shaqlawa Area, Northern Iraq. Iraqi National Journal of Earth Sciences, 11 (1), 23-48.

Jassim, S. Z. and Goff, J. C., 2006 Geology of Iraq, Published by Doline, Prague and Moravian Museum, Brno, $466 \mathrm{pp}$.

Kassab, I. I. M., 1972. Micropaleontology of the Upper Cretaceous to Lower Tertiary of Northern Iraq. Unpublished Ph.D. thesis, University of London, 310 pp. 
Kassab, I. I. M., 1974. The genus Heterohelix (Foraminiferida) from Northern Iraq. Journal of Geological Society of Iraq, 7, $75-94$.

Kassab, I. I. M., Al-Omari, F. S. and Al-Safawee, N. M., 1986. The Cretaceous-Tertiary boundary in Iraq (Represented by the subsurface section of Sasan well No. 1, NW Iraq). Journal of Geological Society of Iraq, 19 (2), 129-167.

Li, L. and Keller, G., 1998a. Maastrichtian climate, productivity and faunal turnover in planktonic foraminifera in South Atlantica, Deep Sea Drilling Project, sites 525A and 21. Marine Micropaleontology, 33, 55-86.

Li, L. and Keller, G., 1998b. Diversification and extinction in Campanian -Maastrichtian planktonic foraminifera of northwest Tunisia. Eclogae Geologicae Helvetiae, 91, 75-102.

Lirer, F., 2000: A new technique for retrieving calcareous microfossils from lithified lime deposits. Micropaleontology, 46, 365-369.

Masters, B. A., 1984. Comparison of planktic foraminifera at the Cretaceous-Tertiary boundary from the El Haria shale (Tunisia) and the Esna shale (Egypt). In: Proceedings of the 7th Exploration Seminar, Cairo, Egyptian General Petroleum Corporation, 310-324

Mousa, A. K., AL-Dulaimi, S. I. and Mohammed, I. Q., 2020. Biostratigraphy of the Late Cretaceous-Early Paleocene Successions at K.H 5\6 And K.H $5 \backslash 8$ core interval, Western Desert of Iraq. Iraqi Geological Journal, 53 (1E), 104-125.

Renne, P. R., Deino, A. L., Hilgen, F. J., Kuiper, K. F., Mark, D. F., Mitchell III, W. S., Morgan, L. E., Mundil, R. and Smit, J., 2013. Time Scale of Critical Events Around the Cretaceous-Paleogene Boundary. Science, 339 (6120), 684-687.

Salih, M. S., AL-Mutwali, M. M. and Aldabbagh, S. M., 2013. Geochemical study of the Cretaceous-Tertiary boundary succession exposed at Dohuk Dam area (eastern Tethys): Northern Iraq. Arabian Journal of Geosciences, 8 (1), 18.

Sharbazheri, K. M., 2008. Biostratigraphy and Paleoecology of Cretaceous, Tertiary Boundary in The Sulaimani Region, Kurdistan, NE Iraq. Unpublished PhD thesis, University of Sulaimani, 219 pp.

Sharbazheri, K. M., Ghafor, I. M. and Muhammed, Q. A., 2009. Biostratigraphy of the Cretaceous-Tertiary boundary in the Sirwan Valley (Sulaimani Region, Kurdistan, NE Iraq). Geologica Carpathica, 60 (5), 381 $-396$.

Sharbazheri, K. M., Ghafor, I. M. and Muhammed, Q. A., 2011. Biostratigraphy of The Cretaceous-Paleogene Boundary in Dokan Area, Sulaimaniyah, Kurdistan Region, NE Iraq. Iraqi Bulletin of Geology and Mining, 7 (3), 1-24. 